\title{
Comparison of Electrochemical Properties Between Portland Cement, Ground Slag and Fly Ash
}

\author{
W. Aperador ${ }^{*}$, J. Duque, E. Delgado \\ School of Engineering, Universidad Militar Nueva Granada, Bogotá-Colombia \\ "E-mail: g.ing.materiales@gmail.com
}

doi: $10.20964 / 110471$

Received: 16 February 2016 / Accepted: 8 MArch 2016 / Published: 1 April 2016

\begin{abstract}
With the aim of generating solutions against the deterioration of the steel embedded in the concrete are studied three cementitious systems obtained from: Portland cement, steel blast furnace slag and fly ash from coal-fired power plants. The main objective was to compare the mechanical performance and durability of each of the systems independently. The cement with steel slag and fly ash alkali activated by combining alkali activators: sodium silicate and sodium hydroxide. The characterization of the powdered raw materials and products formed reaction was performed by analysis of X-ray diffraction. The evaluation of mechanical properties was performed in compression then the concrete will be exposed to the entry of aggressive agents such as chloride ions during 24 months, time when their electrochemical properties were evaluated. The results for various mixtures indicate that these alternative materials (fly ash and steel slag) generate adequate mechanical and durability performance.
\end{abstract}

Keywords: Portland cement, steel slag, fly ash, chloride ions, corrosion.

\section{$\underline{\text { FULL TEXT }}$}

(C) 2016 The Authors. Published by ESG (www.electrochemsci.org). This article is an open access article distributed under the terms and conditions of the Creative Commons Attribution license (http://creativecommons.org/licenses/by/4.0/). 